\section{Community Participation in Bureaucratic Organizations: Principles and Strategies}

\author{
Eugene Litwak, Earl Shiroi, Libby Zimmerman, \\ and Jessie Bernstein/University of Michigan-Tel Aviv \\ University
}

The present paper points out that there are tasks that primary groups perform better than bureaucracies and those that bureaucracies perform better than primary groups. Both types of tasks are very interdependent so that sometimes primary group tasks must be performed within the boundaries of the bureaucratic organization. The argument is made that when primary groups intervene in bureaucracies, they can do so directly in non-expert tasks without lowering the effectiveness of the bureaucratic organization. When they intervene in expert aspects, they should do so indirectly through an expert advocate. However, in all intervention the primary group must take into account that its structure is contradictory to that of the bureaucracy and, therefore, it must keep as much distance as possible - consistent with its ability to intervene. From this analysis we derive a series of hypotheses suggesting when the community might ideally use the bureaucracy's own experts, when the community must hire its own experts, when the community should use mass media, strikes, indigenous workers, etc. It is suggested that the multitudinous possibilities for linkages can all be derived from a few basic underlying dimensions of the situation.

Cet article montre qu'il existe certaines tâches que les groupes primaires accomplissent mieux que les bureaucraties, et certaines autres qu'accomplissent mieux les bureaucraties. Les deux sortes de tâches sont interdépendentes; donc parfois les tâches des groupes primaires doivent s'accomplir parmi les organisations bureaucratiques. Les auteurs soutiennent que les groupes primaires peuvent intervenir dans les bureaucraties en complétant les tâches non-expertes sans réduire l'efficacité de l'organisation bureaucratique. Quands ils participent à certains sujets experts, ils devraient se munir d'un agent expert. Mais dans toute intervention le groupe primaire doit se rendre compte que sa structure contredit celle de la bureaucratie et que, par conséquent, il doit se tenir autant à distance que possible par rapport à sa compétence d'intervention. De cette analyse proviennent des hypothèses qui indiquent quand une communauté peut se servir le mieux du personnel expert d'une bureaucratie, quand la communauté doit engager des experts, quand la communauté doit se servir des mass média, des grèves, des ouvriers indigènes, etc. Les nombreuses possibilités de liaisons proviennent toutes de quelques dimensions fondamentales de la situation.
Recently there has been a great deal of controversy over the question of community participation in large-scale organizations. Much of this controversy has centered around organizations such as the school, police, and welfare departments. In the present paper we examine the theoretical basis for community participation in these organizations and suggest some optimal linkages that would take into account the contradictory structures and the complementary goals of the bureaucracy and of the primary group (i.e., any small face-to-face group that stresses positive affect, non-instrumental permanent and diffuse relations, such as a family or friend).

First we review the alternative theories on the relationship between primary groups and bureaucratic organizations, then discuss some of the variables that affect the linkage mechanisms selected by the primary group. Some generic social situations are discussed in order to illustrate the application of our framework.

The present paper can be considered an extension and elaboration of the article, "A Balance Theory of Coordination between Bureaucratic Organizations and Community Primary Groups" (Litwak \& Meyer, 1966), which concentrated on the opposite problem, that is, how bureaucratic organizations optimally intervene to change community primary groups.

\section{Two Currently Held Views}

\section{Traditional Point of View-}

The Power of the Bureaucracy

The traditional position on the role of bureaucratic organizations and community primary groups has been one that states that bureaucratic organizations will take over most of the functions of the primary group because they are more efficient. Furthermore, because the primary group and bureaucratic organizations have contradictory structures, they cannot both exist in very strong forms in the same society. Thus the stronger one becomes, the weaker the other becomes. This kind of reasoning has prompted many past writers to speak about the change from a folk to an urban mass society dominated by large organizations (Ogburn, 1953; Redfield, 1947; Simmel, 1950; Tönnies, 1940, esp. pp.18-28; Weber, 1952; Wirth, 1957).

Underlying their analyses as to why the bureaucratic organization is more effective than the primary group is generally the theory that the bureaucratic organization can concentrate more knowledge and re- 
sources on solving any given problem than the primary group can. Thus the bureaucratic organization insures optimal knowledge because it appoints and promotes people in terms of their ability to handle the designated tasks. By contrast the primary group member is born (or marries) into the group and is considered a member regardless of his ability to accomplish tasks.

The bureaucracy not only maximizes knowledge by its selection procedures, but it permits on-the-job training by its use of specialization. By contrast a family consists of a small number of people with many different, legitimate tasks. There is a division of labor within the family but there cannot be the degree of specialization that takes place in the work situation. In addition, the bureaucracy, because of its size, can support largescale machinery that leads to effective production, e.g., a factory can have an assembly line, blast furnace, huge drill presses, etc.

The bureaucracy not only has a greater concentration of knowledge, but it must insure the right knowledge is in the right place at the right time. Thus the bureaucracies stress rules to insure that each specialized segment of the organization is doing things that are consistent with its other segments. In those situations where rules cannot be drawn up, then the bureaucracy has hierarchal authority to insure that once a decision is made it will be the same for the entire enterprise. By contrast the family, as a small unit, gains coordination through face-to-face contact.

The bureaucracy further guards against the intrusion of extraneous values or interpersonal likes and dislikes by insisting on a priori delimitation of duties and privileges and impersonal relations. By contrast primary group members are on call night and day. Furthermore, primary groups place a great value on positive affection and as a matter of principle insist that personal feelings come before all else.

Finally the bureaucracy permits change by separating policy from administrative decisions. Thus one can change policies without having to fire the entire organization and starting anew. By contrast primary groups usually have, as one of their chief goals, the internalization of cultural values. To change family policy (e.g., religious beliefs, political beliefs, socialization norms, social manners, etc.) requires a major resocialization process.

What should be clear is that bureaucracies can optimize knowledge by stressing aspects of group structure that are contradictory to that of the primary group.
This is the basis for the traditional view that bureaucracies are most effective and that societies cannot tolerate strong forms of both bureaucracies and primary groups.

With this traditional framework there is only one way primary groups can intervene in the bureaucracy, and that is through appointing people to the top policy boards and working through them. ${ }^{1}$

\section{A Contemporary Point of View}

There is a second point of view, which is currently held by many sociologists. They accept much of the first analysis, but they raise a very important exception. They suggest that there are tasks for which economies of large-scale and expert knowledge are not advantageous. They point out that such activities as early socialization of the child and adult tension management are tasks that are necessary for social survival and that the bureaucratic organizations cannot handle because they require positive affect. (Parsons \& Bales, 1955)

Given the need for tension management and early socialization of the child and given the fact that bureaucratic organizations have contradictory structures to the primary groups, these authors conclude that bureaucratic organizations and primary groups must be kept relatively isolated from each other. If they become too close they will tend to destroy each other. As a consequence, this point of view would suggest that primary groups and bureaucratic organizations retain an alliance at arms distance. Thus, schools with

1 However, they are unlikely to be effective because community primary groups are likely to wane in influence where bureaucracies are strong. This analysis provides the theoretical underpinning for the kind of pessimism generated by people such as Marcuse (1966). It is clear that if any unscrupulous group seized control of these bureaucracies (as is suggested as being inevitable by such people as Michels (1952), Marcuse (1966), and C. Wright Mills) the bureaucracies would become a power unto themselves. Primary groups just do not have the organizational bases to compete with bureaucratic organizations and if they should somehow successfully intervene at any but the most general policy level they will destroy the bureaucracy. Put somewhat differently, this point of view suggests that parents can at best seek to control the board of education so as to set general educational policy but efforts on their part to deal with the everyday running of schools or the details of curriculum will either fail or, insofar as they succeed, destroy the educational system, i.e., replace expertise with nepotism. The same point can bo made with regard to the police. The intuitive acceptance of this analysis is behind the "nihilism" of some student radical movements that suggest that we must reject technological priorities, bring the system down, and start afresh. 
children who are discipline problems or have emotional problems will inform parents and expect them to handle the matter. On the other hand, if the parent feels that the school is not performing its job effectively (e.g., a teacher is drunk in class) then the parent is supposed to protest via the regular bureaucratic channels provided for such occasions (i.e., letter to the principal or superintendent of schools). The actual correction of wrongdoing must be left to the bureaucracy.

To summarize, the clear implication of this approach is that bureaucratic organizations and community primary groups each have their own spheres and neither intervenes in the other. The most each does is to draw the attention of the other to the presumed defects. However, the ultimate judgment and treatment of these presumed defects are left in the hands of the respective groups.

\section{The Balance Theory}

There is yet another point of view that we develop in this paper. It is called the balance theory of coordination (Litwak \& Meyer, 1966).

This point of view agrees with the first premise of both prior positions. The bureaucratic organizations provide the optimal organizational bases for the exercise of power insofar as concentration of specialized knowledge and economies of large scale are important. This viewpoint furthermore accepts the premise that the structures of the bureaucratic organizations and community primary groups tend to be antithetical. In the same way as the second position, the third rejects the assumption that economies of large scale and specialized knowledge are invariably important ingredients for solving problems. However, this position differs in two very important respects from the second one. First, it suggests that primary groups may exercise power in most areas of life (i.e., not just those of tension management and early socialization). Second, it suggests that the great interdependence in tasks between primary groups and bureaucratic organizations means that they can not be kept isolated from each other without causing damage to the achievement of their respective goals. As a consequence, the balance theory predicts that the community and the bureaucracy will optimally achieve their respective goals if they operate at some mid-point in distance from each other. If they are too close their contradictory structures will cause friction. If they are too far they will not have the optimum in organizational resources. Since most persons under- stand the role of bureaucracy and trained knowledge, we indicate first the general bases for primary group power, i.e., when trained knowledge is not important.

\section{The Bases for Primary Group Power- Non-Expert Tasks}

Perhaps one of the most obvious situations where trained experts are of little use is where there is no real knowledge. Thus, there are many frontier areas where we have no specialized knowledge. The treatment of alcoholism, overeating, and drug addiction are but three areas where the current state of knowledge is not sufficiently great to justify highly specialized training or specialized machinery for immediate treatment. ${ }^{2}$ The proof is that in these situations, volunteers with relatively modest training seem to be doing as well as highly trained specialists. Another area where specialized knowledge and resources make little difference is where the task is so simple to perform that the ordinary citizen has enough knowledge to perform it as well or almost as well as the specialist. Thus, the ordinary mother through the ordinary socialization process is almost as good as the expert (i.e., child specialist) in watching a child so that he does not go into the street, and if he does go into the street she is usually as capable as most experts in pulling him out of the way of an oncoming car.

Finally, there are times where the complexity of the situation, its unpredictability, and the need for great speed, make it difficult, if not impossible, to bring experts or large-scale machinery into play in time to do any good. For instance, in our illustration of a mother pulling a child out of the way of an oncoming car, it is not only the simplicity of the act that is at issue, but the inability to anticipate the crisis. Even if an expert were a little better trained, the probability of an expert (doctor) being at the proper place as compared to a primary group member (mother) is very low $^{3}$ and speed is more important than expertise. Sometimes the unpredictability of the event is based on the number of contingencies rather than the inability to anticipate it (e.g., everyday childrearing decision).

2 What wo are saying is that for short-term treatment the expert is not the most effective. We might still want experts in the field because they might be better in the long run.

3 One of the characteristics of primary group relations is face-toface contact in many areas of life and, all other things being equal, this means that primary group members are more often next to each other than are persons involved in secondary social relations. 
To summarize, there are at least three instances where there are no advantages from specially trained experts or from economies of large scale: (1) where there is not sufficient knowledge to make training or designing machinery worthwhile, (2) where the tasks to be done are sufficiently simple so that the ordinary citizen with ordinary resources can do them as well as trained experts with large resources, and (3) where the complexity and the unexpectedness of the situation prevent the special knowledge of experts or the advantages of large-scale machinery from being used. We refer to all such tasks where experts have no real advantage over non-experts as non-expert tasks. What is important to stress is that these tasks constitute a major part of a person's life and cover every area of life (e.g., inside and outside of organizations).

\section{Primary Groups and Speed and Flexibility}

To point out that there are many tasks for which bureaucracies are not more effective than primary groups is only one part of our analysis. We submit that the primary group is not only equal to the bureaucracy but is a more powerful base for handling nonexpert tasks. Our argument is that the very structure of the primary group, which makes it inefficient for developing trained expertise and large resources, makes it a speedier and more flexible decision-making unit for non-expert tasks. First, the primary group does not appoint persons on merit. However, that is no defect if expert knowledge is not a key factor in making a good decision (i.e., everybody has sufficient knowledge). Given this fact, there is a savings entailed by rejecting merit. One can drop the costly procedures that selection and promotion on merit entail. Second, the primary group does not stress detailed specialization. This factor is an advantage, since premature specialization or a specialist who does no better than the ordinary individual is a resource drain on the organization, slows down communication, and leads to inflexibility in decision-making (see, e.g., Vinter, 1967; Wilensky \& Lebeaux, 1958).

The fact that the primary group is a small faceto-face group means that there is almost instantaneous feedback, a factor that becomes very important when dealing with unexpected and complex events. The bureaucracy can compensate for its long chain of command and use of rules where it can take advantage of its superior knowledge base or superior resources. However, when dealing with tasks where knowledge and resources provide no real advantage, the bureaucratic long lines of communication and rules produce inflexible and slower decision-making.

The positive emotional effect of the primary group and its stress on permanent relationships are virtues when non-expert tasks are at issue. In situations of uncertainty, there is often great anxiety (Blau, 1955). In such situations, decisions are much more likely to be implemented and communication is more likely to occur where members have trust in each other as well as long-standing relationships that permit them to understand each other's idiosyncrasies. Permitting positive affect is therefore functional where there are no dangers that emotional states will lead to appointment of the wrong person. Since this is the case for nonexpert tasks and since primary groups permit positive affect and bureaucracies do not, we suggest that the primary group structure is more effective.

The reader should be quite clear what is being said at this point. The claim is made that primary groups are most effective for handling non-expert tasks and bureaucracies are most effective for handling expert tasks.

The balance theory, however, argues that most areas of life have tasks where there is no real expert knowledge; where the situation is too unexpected or too complex to bring to bear expert knowledge quickly enough; or where the ordinary citizen with ordinary socialization and resources can do as well as the trained expert.

Furthermore, there is evidence (Litwak \& Figueira, 1968 ) for arguing that future technology will always insure this situation because technology is as likely to produce small-scale as large-scale economies; because it opens up new areas of ignorance even as it closes down old; and because it simplifies tasks so the ordinary citizen can take over for the experts even as it complicates other tasks so that only trained experts can handle them.

\section{The Interdependence of Primary Group and Bureaucratic Tasks}

We have thus far tried to establish two components of the balance theory. We have pointed out that bureaucratic organizations and primary groups are able respectively to handle different tasks more effectively. We have also suggested that they are able to do so because they have different, in fact contradictory, structures. ${ }^{4}$ What we now want to establish is that these 
two types of tasks are often intertwined so that bureaucracies and primary groups must work in close coordination. There is a certain face validity to this statement. For instance, it is clear that a doctor is helped enormously in his task of keeping people healthy if his clients do such non-expert tasks as maintaining good diets, taking proper exercise, etc. Teachers have a much easier time teaching if the child comes to school with an interest in education, properly fed and clothed. In all instances it is equally clear that primary groups can achieve their goals of health, education, etc., by use of experts. The exact degree of interdependence of community primary groups and bureaucracies can be measured by asking ourselves to what extent do expert and non-expert tasks require the same person, the same time, and the same place. For instance in the school situation, one can think of at least a three-point scale. Toward the independent pole of the scale would be the non-expert tasks that can be performed within the confines of the family and the expert tasks that can be performed within the confines of the school. Such tasks involve different people, different places, and frequently different times. For instance, the family supervision of homework and the development of early language skills have a very important consequence for the type of teaching materials and the speed with which the teacher can transmit information in the classroom. These two activities are separated by place, by type of persons involved, and by time.

At the other extreme, we have the case where the expert tasks are so interdependent with non-expert tasks that they cannot be separated in place, time, or even people. For instance, it is difficult to separate classroom discipline and value socialization from the transmission of educational knowledge (e.g., math, geography). The first kind of task has more degrees of non-expertise than the second kind. Both types of tasks have to take place at the same time and same place and often the same person has to handle both.

In between these two extremes we have tasks that

1 There are some persons who, in their enthusiasm for participant democracy, assume the Marxian utopia has arrived (i.e., that anybody can substitute for anybody else and therefore everybody should have equal participation in all matters). What they are in effect doing is denying the role of experts. This kind of thinking leads one to patently false conclusions (e.g., saying that passengers should participate equally with airplane pilots in all decisions on landing airplanes, that patients should participate equally with doctors on where an incision should be made, etc.). can be separated by people and frequently by time or by place. Thus, the Board of Education makes educational policy (generally involving non-expert tasks) that is implemented by the staff and that involves expert tasks. There is some separation in place and by people in that the Board generally meets in a central building that is physically isolated from the bulk of the school staff and has contact with only a limited number of staff members, e.g., the superintendent of schools. Street guards and luncheon attendants, who are indigenous to the neighborhood, are also performing basically nonuniform tasks and are separated from the professional staff by time and place.

We have now sought to establish the following points. The bureaucracies are best able to handle expert tasks, the primary groups are best able to handle non-expert tasks, the structures of the two organizations are contradictory, and the tasks are interdependent (i.e., to achieve most goals one needs to deal with both expert and non-expert tasks).

These points set the basis for the "balance theory of coordination" as well as suggesting the theoretical bases for community intervention. The balance theory suggests two kinds of dangers. First, the fact that the community and the bureaucracy are not sufficiently linked to coordinate their activities means that the overall goal achievement of both organizations suffers because either the non-expert or the expert parts of the goals are not carried out. The second kind of danger emerges where the primary group members and the bureaucrats are brought into intimate everyday contact. Because of their conflicts in structures and norms, this contact could lead to serious friction between them. Alternatively it could lead to the introduction of contractual bureaucratic norms into the primary groups or the nepotistic, familistic norms into the bureaucracy. Any one of these alternatives would mean that the expert or non-expert aspects or tasks would not be done. ${ }^{5}$

Given the above analysis of danger from too close or not enough contact between organizations, the balance theory hypothesizes that optimal linkages between community primary groups and bureaucratic organi-

5 Kramer (1969) has an excellent description of the problems of too much closeness and too much distance. Thus he points out cases where too much closeness has led to nepotism and corruption, as well as cases where the bureaucracy did not serve the goals of the poor that it was presumably set up to do. 
zations are at some "middle point"-not so close as to cause structural friction and not so far as to cause lack of coordination.

If this theory is correct, then the community seeking to influence the bureaucracy must make one of several diagnoses: (1) Is the bureaucracy too distant, too close, or at the optimum point of balance? (2) What aspect of the bureaucracy do they want to influence-non-expert tasks or expert tasks?

\section{Principles of Community Linkages to Bureaucratic Organizations}

The analysis suggested by the balance theory permits the generation of more specific principles of community linkages to bureaucratic organizations. The first basic principle derives from the argument that primary groups and bureaucratic organizations have their own spheres of effectiveness. The principle states that if a community primary group seeks to change experttechnical tasks within a bureaucracy it must have a linkage procedure that provides the community with experts. If a community primary group seeks to change nontechnical tasks of the bureaucracy, it need only have primary group members as links to the bureaucracy. Illustrative of a community using experts to link to the school would be where the community hired a lawyer to sue the schools. All linkages that have experts in them are called linkages with "bureaucratic intensity." Illustrative of the use of primary group members as linkages to the school would be marches, boycotts, and direct parental talks with teachers. Linkages that consist of primary group community members are called linkages with "primary group intensity." Thus the first principle can now be restated as follows: When community primary groups seek to influence bureaucracies on technical matters, they should have linkages with bureaucratic intensity; when they seek to change non-expert matters within the bureaucracy, they should have linkages with primary group intensity.

The second principle of linkages rests on the need for the community to establish a balanced relationship in order to avoid the conflicts between their structures and the bureaucracy. The second principle states that when the bureaucracy and the community are very close, the community should use linkages that open up distance between it and the bureaucracy; when the community and the bureaucracy are too far, they should have linkages that bring them closer together. For instance, when the school and community are in very close agreement about the need to establish a Black curriculum then the community can delegate the task of writing a Black history test to the school's experts and keep very indirect contact. However, if the school is against the introduction of a Black curriculum and the community is for it, then the community must insure very close contact with the experts-usually hiring their own experts.

If these two principles are simultaneously stated, then we have the four propositions indicated in Table 1. First one should look at whether the target of change is in a technical or nontechnical area. Thus if we are dealing with a technical area and the community and school are too close, one delegates the change to the experts in the school staff and exercises only indirect supervision (see No. 3, Table 1). If the problem is one of great distance, then one hires one's own experts and keeps close surveillance over the school staff (see No. 4 , Table 1). If the problem is a non-expert task and the school and community are too close, then one moves to a highly centralized contact through very few staff members, e.g., a centralized board of education (No. 1, Table 1). However, where the school and community are too far, one needs close supervision and moves to a procedure that provides closer face-to-face contact with many staff members, e.g., decentralized boards of education (No. 2, Table 1 ).

These same principles hold whether the expert and non-expert tasks are closely intertwined or not. For instance, we suggested that classroom socialization and

Table 1/Community Linkage Hypothesis Based on the Balance Theory

\begin{tabular}{|c|c|c|}
\hline & $\begin{array}{l}\text { Non-Expert Task: } \\
\text { e.g., setting policy }\end{array}$ & $\begin{array}{l}\text { Expert Task: } \\
\text { e.g., writing } \\
\text { history test }\end{array}$ \\
\hline $\begin{array}{l}\text { Community and } \\
\text { Bureaucracy Close: } \\
\text { e.g., both agree } \\
\text { Black curriculum } \\
\text { is good }\end{array}$ & $\begin{array}{l}\text { 1.Highly Central- } \\
\text { ized and Limited } \\
\text { Contact: e.g., } \\
\text { centralized board } \\
\text { of education }\end{array}$ & $\begin{array}{l}\text { 3.Delegate Tasks } \\
\text { to School Bureau- } \\
\text { cracy: e.g., history } \\
\text { teachers selected by } \\
\text { staff to design text }\end{array}$ \\
\hline $\begin{array}{l}\text { Community and } \\
\text { Bureaucracy } \\
\text { Distant: e.g., } \\
\text { community wants } \\
\text { Black curriculum } \\
\text { and school staff } \\
\text { does not }\end{array}$ & $\begin{array}{l}\text { 2.Decentralized } \\
\text { and Close Contact: } \\
\text { e.g., decentralized } \\
\text { board of education, } \\
\text { local community } \\
\text { veto power of } \\
\text { teacher hiring }\end{array}$ & $\begin{array}{l}\text { 4.Community } \\
\text { Uses its Own } \\
\text { Experts: e.g., hires } \\
\text { own historians or } \\
\text { has power to name } \\
\text { school staff who } \\
\text { will design text }\end{array}$ \\
\hline
\end{tabular}


discipline (non-expert tasks) are very interdependent with the exchange of technical knowledge, such as math or geography (expert task). We would argue that the community could handle the nonuniform aspects through varying degrees of contact with the staff. The most distance would be achieved by hiring a superintendent and trusting him to hire a principal and teacher who share common socializing and disciplinary values with the community. There would be less distance if the community insisted not only on hiring the superintendent, but also on having veto power over hiring the principal. These two, in turn, would hire the teachers who reflected the community's proper values. Finally, the least distance arises where the community members insist not only on all of the prior activity, but also upon a parent sitting in the classroom in order to insure that the teacher operates according to community norms. Our hypothesis would tell us that the first procedure would be very appropriate where the community and staff were very close, while the latter procedure would be most appropriate if the community and staff were very distant or hostile to each other.

\section{Stages or Sequences of Change}

The question arises about what else one must know in order to speak about the properties of linkages for closing and opening distance, as well as the capacities for dealing with expert and non-expert tasks. It has been pointed out that when bureaucracies seek to influence primary groups there are at least two blocks that they must overcome to close distance with a hostile audience. First is what has been called "selective listening" (Hyman \& Sheatsley, 1947). People systematically refuse to even listen to messages that go counter to their beliefs. Thus, a Democratic candidate for governor might never reach Republican voters when he appears on television because Republican voters systematically refuse to tune in on speeches from opposing candidates. A second block in communication arises where one manages to overcome the first block. In this instance the audience "selectively interprets" or forgets that part of the message to which they are hostile so as to make it conform to prior beliefs (Hyman \& Sheatsley, 1947).

The above analysis suggests that there are at least two steps that must be undertaken if one is to deal with a hostile audience: (1) to get their attention, and (2) to insure they have absorbed the right message. Furthermore, these two steps are independent of each other. It is possible to get the audience's attention without necessarily getting them to absorb the message. In addition, it is possible that the technique for getting their attention might not be the same as the technique for change.

To make this point very clear, let us consider the two techniques we have mentioned thus far as available to the community groups. They can use linkages with primary group intensity (primary group members) when dealing with non-expert tasks and linkages with bureaucratic intensity (professional advocates) when dealing with expert tasks. Getting the bureaucratic attention may or may not be an expert's task. Similarly, the task of changing the organization may or may not involve experts. As a consequence, there are four possible sequences that might confront the community: (1) getting the attention of a bureaucracy is best handled by the community, but the problem of change involves experts; (2) getting the bureaucracy's attention and getting change involves the community; (3) getting attention and change might involve experts; (4) getting the bureaucracy's attention might involve experts, but getting change might involve the community. To illustrate, a community might utilize boycotts or strikes (primary group intensity) to get the school to set up a Black history course (which requires expertise). Or the community might institute a boycott or strike (primary group intensity) to get the school board to put local people in a position to make policy (nonexpert primary group intensity). The community might hire a lawyer (expert) to sue the school system in order to get it to create a Black history course (involving experts) or the community might hire a lawyer (expert) to sue the school board in order to get it to put local people on the boards of education for making policy (primary group-non-expert).

Thus, in our analysis, we want to consider both the process of getting the bureaucracy's attention and the process of change as two distinct steps that are analogous to the problem of selective listening and selective interpretation that occurs when the bureaucracy seeks to change the primary group. However, before pursuing this analogy too much further, we speculate on how, in fact, the bureaucracy selectively listens so as to avoid community messages that it does not like and, if it is forced to hear the message, how it selectively interprets so as to prevent changes it does not like. This analysis, in turn, gives us a much more precise idea of the types of linkages one must employ. 
Getting the Bureaucracy's Attention-

Problem of Selective Perception

Following our prior analysis we suggest that the problem of getting the bureaucracy's attention might be either an expert or a non-expert task. First, we illustrate the cases where the task involves experts and then the cases where it involves non-experts. One of the major reasons for selective listening lies in the fact that bureaucracies involve specialization and knowledge above and beyond that available to the ordinary individual. As a consequence, the ordinary citizen does not have the knowledge to know which bureaucracy to go to or where to enter it. Therefore, his message is often never received by the right bureaucracy. A classic illustration of this point is the case of some New York tenants who found their water and heat turned off in midwinter (Purcell \& Specht, 1967). There were five city agencies that dealt with water, i.e., one to turn it on, one to turn it off, one to handle faulty plumbing, one to keep it hot, one to handle water rates.

If a tenant managed to find the right organization he was not necessarily sure where best to enter the organization to get some results (e.g., who to speak to, whether to sue in court). If one understands that the ordinary citizen has a myriad of such organizations that he must deal with in his everyday life and that each has specialized rules and regulations, it becomes clear that in principle he would not have the kind of knowledge necessary to deal with his organizational environment.

A second factor that leads to distortion of community messages is that the bureaucrat assumes that anything offered by an "amateur" is suspect. He assumes that only bureaucracies deal with expert tasks and as a consequence experts are the only ones who can diagnose problems, etc. A third factor that often leads to distortion of messages is that any bureaucrat who is unsympathetic to the community can confuse the community by giving them wrong information. Thus, a principal in a school might tell parents that he cannot introduce a new curriculum because state law forbids it. He might not tell them that the law also has a clause that permits new curriculum in schools for experimental purposes. As a consequence, the community's desires never get beyond the principal's office. Finally, it can be argued that the community's message never gets through to the bureaucracies because the community primary groups do not have the resources to wait until the message winds its way through bureaucratic channels. Thus in the case where the families were without water and heat in the winter, they needed a decision within a few days and the bureaucracy took much longer to even acknowledge the message.

If the reader considers all of these reasons for message distortion, he will find that they all involve a lack of expertise on the part of the community. This situation leads us to one of our balance theory principles. In order to avoid selective listening on the part of the bureaucracy on issues that have to do with technical matters, the community should have an expert advocate. Kahn, Grossman, Bandler, Clark, Galkin, and Greenwalt (1966) make this a central point in their advocation of local community information centers. It is the basic principle of the ombudsman concept as well.

However, we would also suggest that sometimes communities can get bureaucratic attention without having to appeal to expert advocates. The optimal circumstance for doing so is where communication success can be evaluated by the non-expert and where the bureaucracy is highly dependent on or vulnerable to the primary group. Thus, in our illustration we suggested that the principal could fool the community because it lacked technical knowledge of the law. In such a case, the community could not properly assess the success of the communication. However, there are many instances where it is a simple matter to assess whether the communication has been received or not, e.g., whether the board of education puts on its agenda an item on Black curriculum. In addition, we think that bureaucracies have differential dependence on primary groups. Thus a retail merchant tends to be more vulnerable to primary group pressure than is a wholesale merchant; a political party right before an election is more vulnerable than right after; business concerns are more dependent on their workers than welfare agencies are on their clients, etc. We would argue that where the bureaucracy is vulnerable and the assessment of communication simple, the community can get bureaucratic attention by use of linkages with primary group intensity-strikes, boycotts, petitions, etc.

Thus based on our balance theory approach we would argue that the communities can overcome problems of selective listening and get bureaucracies' attention if they use linkages with bureaucratic intensity for handling the expert problems, and linkages with primary group intensity for handling the non-expert problems. 


\section{Getting the Bureaucracy to Change-}

\section{Selective Interpretation}

We would make the same logical analysis for change as we would for insuring the bureaucracy's attentiveness. Thus we would say that some change problems involve experts and some involve non-expert tasks and the community should use linkages that permit the use of experts and primary group members for each as necessary. To make this point clear, one can enumerate the number of ways in which organizations can change - personnel can be fired, new people hired, people can be retrained, rules or machinery can be changed, administrative styles of the organization can be changed. We would argue that all of these processes have both expert and non-expert aspects to them. Thus the assessment of a teacher might involve an assessment of his mathematical abilities (something only an expert mathematician can determine) as well as an assessment of whether he has basic values that are similar to the parents or not (something the parents can best determine). Some people take the position that teachers have no expertise at all and as a consequence the parents can do the entire job of teaching (Rogers, 1969). There are teachers who feel that parents have no role in the change process of schools. We do not adopt either of these extreme positions. We think that the making up of curriculum does involve expertise (e.g., people who know history) and must take into account the community (e.g., to assess if the teacher shares common values). If the primary group seeks to make up its own curriculum and to judge the technical expertise of the teacher, then the quality of education will drop. On the other hand, we think that the teachers who seek to make judgments as to what is good for the community and what the community values should be without consulting the community directly will also succeed in lowering the educational quality of the school.

We would further suggest that the bureaucracy can resist the community on changes in areas of expertise in the same way they selectively screen out messages in technical areas-the community lacks enough information to know what has to be changed, to know whether change has taken place or not, or to have the time for change to take place. Therefore we would suggest that to handle change in expert areas the community must have expert advocates. Following the same logic we would argue that to have change in non-expert areas one could have direct intervention on the part of the community.
Variable Social Distance, Selective Perception, and Change

The analysis thus far speaks about the need to have the community use experts when dealing with technical tasks-be they ones of selective listening or selective interpretation. Similarly, when dealing with nontechnical tasks our analysis suggests that the community use linkages that contain primary group members. To this analysis we would now add our second principle-the primary groups and the bureaucracies should be kept at a balance point. Thus, if the task is to insure that the teacher has the proper values and the school and community are quite friendly, then the community can use a linkage that minimizes the amount of face-to-face contact between community and teachers. The community, through a large centralized board of education, hires a superintendent, who in turn hires everyone else. If there were bitter enmity between staff and community, the community would have to sit in the classroom to insure that its values were preserved. The hostility between staff and community insures that they will not engage in nepotism or favoritism. Between these two extremes would be the insistence on the community's part of giving local boards of education rather than central boards veto power over hiring the principal or the teachers. If the task were a technical one, then the community could avoid contact with experts by having the bureaucracy handle its technical tasks. Where the bureaucracy and community are unfriendly, it is necessary for the community to hire its own experts to handle the technical problems. The fiercer the combat, the closer the community has to be with its own experts.

We have tried to do two things in this section. First we have suggested the two principles of linkages based on the balance theory: (1) linkages can be directly handled by the primary groups where the task is nonexpert, and by advocate experts when they are expert tasks, and (2) linkages must keep community and bureaucracy isolated when they are too close and bring them closer together when they are too far. In addition, it was pointed out that there are at least two stages to any influence process-getting the bureaucracies' attention and producing change. These can demand entirely different linkages from a community.

\section{A Classification of Linkage Mechanisms}

On the basis of the above discussion we are now in a position to suggest some of the fundamental properties of linkages that enable us to anticipate whether they will 
permit the community to shrink social distance or maintain it. The underlying dimensions that have emerged from the above discussion are bureaucratic intensity, primary group intensity, interdependence of expert and non-expert tasks, and, one we have yet to discuss, scope (i.e., the extent to which the linkage mechanism permits one to reach many people or few). If our estimate is correct, these fundamental dimensions can be used to evaluate any empirical linkages as well as suggesting new ones. To illustrate this point we take a series of ways in which communities have sought to influence bureaucracies and roughly rank them on the proposed underlying dimensions. The following are some of the ways the community has influenced bureaucracies in the past.

1. Advocate bureaucracy. The primary group develops its own bureaucracy to deal with the target bureaucracy. It can either develop its own as the union did to deal with management, or it can, through political processes, take over an ongoing one as political parties take over governmental agencies, or it can seize one through force as happens in revolutionary movements. 2. Delegated bureaucracy. What characterizes this approach is that there is an already formed organization to which the community member can turn (e.g., a Race Relations Commission or an ombudsman).

3. Voluntary association. Communities may have voluntary associations rather than full-fledged bureaucracies represent them. Unions prior to their full-fledged bureaucratization were voluntary associations, the parents in Oceanhill-Brownsville had a voluntary association, etc.

4. Mass media. Frequently the community can best reach the bureaucracy through mass media. This approach is associated with public marches or riots, etc. 5. Indigenous expert. These are persons hired by a bureaucracy and who live in the immediate neighborhood, e.g., teachers who live in their school district.

6. Proto-indigenous expert. These are experts hired by the bureaucracy and who have backgrounds similar to the community, e.g., Black teachers in Black communities, or who have special training to make them sensitive to the local community, but do not live in the immediate neighborhood.

7. Low-powered indigenous non-expert. These are community members who act as street-crossing guards, lunchroom attendants, and as school and community aids in welfare agencies.
8. High-powered indigenous non-expert. These are members of boards of education who set policy or who have veto power over the hiring and firing of personnel.

9. Systematic sustained boycott, strike, or violence. Illustrations are long-term union strikes, bus boycotts, and the French Resistance movement. Usually these mechanisms must be associated with a bureaucracy or a voluntary association.

10. Ad hoc riot, strike, boycott. The big city "ghetto" riots, as well as spontaneous short-term boycotts or strikes by parents and students against schools.

11. Mass march. The peace marches and civil rights marches on Washington, and the Black organizations marching in Pittsburgh to attract attention to their demands for more skilled jobs are illustrative.

12. Single person ad hoc contact. The parent who comes in to complain about a teacher, or to get more information on a school program illustrates this mechanism.

It is clear that we have not exhausted all possible forms of linkage. It is also clear that the ones we have delineated can be combined in many different ways.

In Table 2 we list the mechanisms and their ratings on each of the underlying dimensions. The column headings are the underlying dimensions while the row headings are the empirical linkages. These ratings are rough approximations that suggest the logic of our procedure. The actual ratings would have to rest on empirical research.

With this in mind let us examine column one on bureaucratic intensity. Our ratings are based on the extent to which the linkage mechanism used by the community is itself a bureaucracy under the control of the community. Thus, the advocate bureaucracy has the highest ratings and is best represented in current American society by honest union bureaucracies and their membership. The linkages with the least bureaucratic intensity would be the single person contact.

In regard to the next column, labeled primary group intensity, the linkages in which community members are the major element, have the highest ratings. It is important to note that there are linkages such as the indigenous experts or proto-indigenous experts who are high on both primary group and bureaucratic intensity. Thus it is possible for one mechanism to be fairly high on both dimensions. It is also possible to think of degrees of primary group intensity. Thus a 
Table 2/Hypothesized Rating of Some Linkage Mechanisms on Basic Underlying Dimensions of Linkages

\begin{tabular}{|c|c|c|c|c|}
\hline Variable & $\begin{array}{l}\text { Bureaucratic } \\
\text { Intensity }\end{array}$ & $\begin{array}{l}\text { Primary Group } \\
\text { Intensity }\end{array}$ & $\begin{array}{l}\text { Interdependency } \\
\text { of Expert and } \\
\text { Non-Expert Task }\end{array}$ & Scope \\
\hline $\begin{array}{l}\text { Advocate bureaucracy-community } \\
\text { has its own bureaucracy-unions }\end{array}$ & Highest & Low & Mod-Low & High \\
\hline $\begin{array}{l}\text { Delegated bureaucracy--community } \\
\text { borrows ongoing bureaucracy-lawyers }\end{array}$ & High & Lowest & Low-Mod & Mod-High \\
\hline $\begin{array}{l}\text { Voluntary association-community } \\
\text { has its own voluntary association }\end{array}$ & Mod & Mod & Mod & Mod \\
\hline Mass media & Mod-Low & Low & Low & Highest \\
\hline $\begin{array}{l}\text { Indigenous expert-teacher who } \\
\text { lives in the area }\end{array}$ & High & High & Highest & Lowest \\
\hline $\begin{array}{l}\text { Proto-indigenous expert-Black } \\
\text { teachers for Black children but not } \\
\text { living in neighborhood }\end{array}$ & High & Mod & High-Mod & Mod-High \\
\hline $\begin{array}{l}\text { Low-powered indigenous non-expert-- } \\
\text { school-crossing guard }\end{array}$ & Low-Mod & High & Mod-Low & Mod \\
\hline $\begin{array}{l}\text { High-powered indigenous non-expert- } \\
\text { board of education with veto power } \\
\text { over hiring and firing }\end{array}$ & Low-Mod & Mod-High & Mod-High & High \\
\hline Organized boycott, strike & Mod & Mod-High & Low-Mod & High-Mod \\
\hline $\begin{array}{l}\text { Ad hoc boycott, strike-one-day } \\
\text { affairs, short-term riots }\end{array}$ & Low & High & Low & Mod-High \\
\hline $\begin{array}{l}\text { Mass marches-civil rights marches, } \\
\text { peace marches }\end{array}$ & Low & Mod-Low & Low & High-Mod \\
\hline $\begin{array}{l}\text { Single person ad hoc contact- } \\
\text { complaints or requests for information }\end{array}$ & Lowest & High & Low-Mod & Low \\
\hline
\end{tabular}

central city-wide board of education does represent community interests versus expert interests but the community it represents is a very large one and may lack the continuous contact and trust of a true primary group.

In examining the third column on the ability of the linking mechanisms to deal with interdependent expert and non-expert tasks, we suggest that all situations where the expert is indigenous to the community or where he had similar values and background to the community are rated high. We also hypothesize that a local board of education with veto power over hiring and firing of teachers is also high on this dimension. Individual contacts by themselves are not linkages that enable one to deal with both non-expert and expert tasks simultaneously. Where the community group engages experts on its behalf (e.g., advocate bureaucracies) there is some ability to handle both tasks but the rating is not necessarily high (e.g., a lawyer can sue in court without having to emphasize non-expert tasks).

The last column concerns the number of people that can be reached by a given mechanism. It is important to note that indigenous experts probably have the lowest scope in a society such as ours. The probability of finding indigenous experts progressively decreases the smaller the size of the community primary group and the lower the income of the neighborhood. By contrast it is more possible to find the proto-indigenous experts. The community-wide policy board has a wide scope but the local board has lower scope. The single 
person contact, in the same way as the indigenous expert, has a very low scope.

It can be seen how this classification of empirical linkages is highly suggestive as to when communities should utilize certain procedures. Thus we suggest that communities should resort to advocate bureaucracies or delegated bureaucracies when they are confronting massive resistance from their target bureaucracies and technical tasks are at issue. At the same time, it is clear that, where bureaucracies are highly vulnerable to primary groups, mechanisms utilizing simple primary group dimensions, such as a parent protesting or ad hoc boycotts or marches, can be very effective in changing the bureaucracies.

\section{Some Generic Social Situations and Ideal Forms of Linkages}

With the above classification of linking mechanisms, we need only one more ingredient to pose a series of hypotheses or policy recommendations for ideal forms of linkages. What we need is a sufficient description of the environment to say whether the bureaucracy and the community are at some distance or not, whether the task to be changed involves experts or non-experts, whether the two types of tasks are heavily interdependent, which stage of the communication process we are in, and the structure of the target bureaucracy that the community seeks to influence. Ideally what one would like to do is to study all these factors simultaneously. However, for purposes of presentation we examine them three at a time. These initial discussions should permit a researcher, policy-maker, or community member to infer what types of linkages would be ideal for the more complex situations.

\section{Social Distance and Type of Task}

In our first analysis we simultaneously consider three factors-the social distance between the bureaucracy and the community, the type of task to be changed, and the sequencing of attention linkages and change linkages. In Table 3 the headings of each column indicate the degree of distance (i.e., bureaucracies friendly or not friendly), the headings of each row indicate the type of task and degree of interdependence (i.e., expert task, non-expert task, interdependent expert and nonexpert tasks). For purposes of presentation we have simplified and dichotomized very complex continuums.

Within each cell we have indicated the sequence of mechanisms for getting attention and change. Putting all these variables together in this way reveals some relations that might not be obvious if each were considered separately. For instance, where the bureaucracies are friendly or vulnerable the community has only to use linkages with primary group intensity, even where expert tasks need to be changed; the reasons being that where the bureaucracy is friendly or vulnerable the community primary groups can always borrow the bureaucracy's resources or experts to make changes. By contrast, where the target bureaucracy is hostile, the community always needs linkages with bureaucratic intensity (even for non-expert tasks) in order to get the attention of the target bureaucracy. With these thoughts in mind, let us briefly review some boxes in the table and see the kinds of predictions our theory suggests.

Cell IV-Bureaucracy is not Friendly and the Task to be Changed Involves Expertise. This might be a situation where the bureaucracy resists any efforts on the part of the Black community to decentralize the school, introduce new courses, or change their staffing policy. In such a situation, we hypothesize that, to get the attention of the bureaucracy, the community primary group has to develop bureaucratic power of its own through an advocate bureaucracy or a delegated bureaucracy. The development of union bureaucracies was in part necessitated by the recalcitrance of management bureaucracies that refused recognition and were able to utilize their resources to enforce it. On the school scene it may involve Black parents going to the NAACP to sue the school system or forming their own organizations (e.g., Oceanhill-Brownsville) to produce a sustained and systematic boycott and going to churches for space to set up private classes so that their children will not lose by a systematic boycott. All of these procedures are designed to get the bureaucracy to pay attention. However, if the bureaucracy agreed to the changes, the community would insist on having its own experts draw up decentralization plans, write new texts for Black history, or insure that new procedures on staffing were being followed, since a hostile bureaucracy cannot be counted on for this kind of expertise.

Cell V-Bureaucracy Is Not Friendly and the Task Involves Non-Expertise. We again might have a bureaucratic organization that is recalcitrant, but in this case the desired changes involve moving different community people into the bureaucracy. For instance, the community might want to have new people and different 
Table 3/Ideal Community Linkages Under Varying Conditions of Social Distance and Types of Task

\begin{tabular}{|c|c|c|}
\hline Type of Task & Bureaucracy is Friendly or Vulnerable & $\begin{array}{l}\text { Bureaucracy is Not Friendly or } \\
\text { Vulnerable }\end{array}$ \\
\hline $\begin{array}{l}\text { Task to be changed is technical involving } \\
\text { expertise or large-scale resources, e.g., } \\
\text { develop Black history curriculum; set up } \\
\text { detailed decentralization plan; set up } \\
\text { detailed desegregation plan. }\end{array}$ & $\begin{array}{l}\text { I. Primary group intensity to attract } \\
\text { attention and that is all the community } \\
\text { has to do. The bureaucracy provides the } \\
\text { expertise for the change, e.g., ad hoc } \\
\text { group of parents petition school for Black } \\
\text { studies program and the school provides } \\
\text { the money and staff to set up the } \\
\text { program and train the teachers. }\end{array}$ & $\begin{array}{l}\text { IV. Bureaucratic intensity to attract } \\
\text { attention and produce change, e.g., } \\
\text { advocate or delegated bureaucracy } \\
\text { threatens legal suit, systematic and } \\
\text { prolonged disruption or setting up } \\
\text { competitive system to get the attention } \\
\text { of the target bureaucracy as well as } \\
\text { employing experts to set up the curriculum } \\
\text { to evaluate teacher-training. }\end{array}$ \\
\hline
\end{tabular}

Task to be changed is non-expert task, e.g., general racial policy on staffing; general curriculum policy on time to be spent on social studies, music, etc.; supervision of children crossing streets, or in the school during the lunch periods.

Tasks to be changed are interdependent, e.g., assessing classroom disciplining behavior, classroom racial attitudes, etc.
II. Primary group intensity to attract attention and produce change, e.g., parents get together to elect new central board members who represent their values and change policy accordingly. They recommend more Black teachers to be hired, Black history should be part of the curriculum, etc. One can rely on staff to implement policy.

III. Linkages with primary group intensity and some interdependence, e.g., parents have power to veto hiring and firing of superintendent and principal and leave it to their discretion to hire teachers.
V. Bureaucratic intensity to get attention and primary group intensity to get change, e.g., use advocate or delegated bureaucracy to organize systematic disruptions, institute suits in court to get attention of the bureaucracy to develop local boards of education that would ensure that parents' values are to be carried out in each school building.

VI. Linkages with both primary group and bureaucratic intensity as well as linkages that permit great interdependence for attention and change, e.g., advocate bureaucracy with threats of systematic disruptions, suits, etc., together with the demand that parents sit in on classroom sessions, have veto power over hiring and firing of teachers, as well as all other school staff, and the use of advocate bureaucratic sources to draw up decentralization plans. policies in the board of education. However, now they confront a determined opposition in the bureaucracy. This bureaucracy might be willing to put its professional resources into any battle for the board of education. In this case, for the community to win, it must have similar resources to hire newspaper space, to get out its constituency, etc. However, once in power they need a linkage with primary group emphasis to ensure that their policy is implemented. If the bureaucracy is really against the policy, then the primary group linkages must permit no delegation of authority to bureaucrats. For instance, if the board of education decides that it wants to experiment with decentralized systems and the teachers are against it, then the board has also to de- centralize its activities (e.g., local board of education) in order to supervise the teachers. This is true because general policies have so many contingencies that a single central board could not begin to police them. From a theoretical point of view, the student of complex organization might note that this solution to policy is different from Weber's, which suggested that policy be made only at the top of the organization, as well as different from the human relations approach that suggests that the bureaucrat internalize the policy (Blau, 1955). It provides a theoretical rationale for the concept of participant democracy in a large-scale bureaucratic organization without having to imply that differences between experts and non-experts are trivial. 
The latter is often the rationale behind people arguing for such localized decision-making.

\section{Elaborations of Social Distance and} the Use of Delegation and Scope-Secrecy

The concept of social distance can be elaborated and approached from a slightly different angle to highlight one of the implicit hypotheses in Table 3 . In thinking of social distance, we suggest that the bureaucracy can be hostile to the local primary group or the larger community can be hostile to it or any combination of the two can occur. This elaboration of the situation permits one to highlight the role of scope in linkage mechanisms. Thus, where the larger community is in sympathy with the smaller community and the target bureaucracy is resistant, it is to the obvious advantage of the smaller community to concentrate on linkages that stress high scope. On the other hand, where the smaller community is facing a larger community that is hostile but has a target bureaucracy that is friendly, the smaller community must stress linkages that have low scope, i.e., reach only the members of the bureaucracy rather than the larger public. Thus, the smaller community might develop a volunteer organization that school staff can join as citizens and provide expert information. Or the school staff might surreptitiously leak information to the voluntary association. This might be the case where the larger community is for public aid to parochial schools while the public school staff and the smaller community oppose it.

Perhaps the situation that might trigger off the most secrecy is the one where both bureaucracy and the larger community are against the local community. Under these conditions the local community is likely to get squashed if it seeks change unless it initially operates very secretly (low scope) to build some organizational apparatus-usually a voluntary association and then a full-blown bureaucracy. Once the smaller community has developed its bureaucratic resources the situation is quite likely to lead to violence. Initially the violence is more like guerrilla warfare, but this can readily escalate into a pitched battle between two or more bureaucracies that might approach a more specialized military pattern. Thus, the UAW in seeking to organize the Ford Motor Company in the early 1940's was up against a trained private army and it developed specialized "flying squads" to deal with them (Bernstein, 1970). The sequence of linkages we have mentioned is typical of the development of trade unions in American society. It also can be seen emerging in the Black militant movement. To conclude these remarks on social distance, we point out that the greater the detail with which we can define the outer environment, the more we appreciate the theoretical importance of scope as a dimension of linkages. In this regard we must also note that people and organizations may not be free to alter their shapes at will. They might in turn be instruments of larger social change processes, e.g., class conflicts, technological innovation.

\section{Organizational Structure \\ and Community Linkage Procedures}

Another characteristic that is often related to social situations is the structure of the target bureaucracy. To make this point clear, let us examine three different types of bureaucratic structures: the rationalistic, rulesoriented structure; the collegial-human relations-democratic structure; and the laissez-faire structure. The first is the classical bureaucracy that we have described before. It has specialization and hierarchal authority for handling situations that cannot be specified ahead of time, rules and regulations for situations that can be specified ahead of time, administrative discretion within each specialty, but no role in policy-making, impersonal relations, etc. The collegial structure moves in the opposite direction, except it does not go as far as primary groups and very much retains merit as a basic criterion. Nevertheless, there is far less emphasis on specialization. Small family service agencies or psychotherapeutic treatment homes, advanced graduate departments in first-rate universities, advanced research institutes, all tend to follow this model (Litwak \& Meyer, 1965; Perrow, 1967). In terms of educational philosophy the first model is consistent with a drill or learning machine approach, while the second is consistent with a pupil-centered approach. In contrast to either of these situations, the laissez-faire model is characterized by each individual doing his "own thing" with no common values or coordination. It is basically the collegial model without coordination.

Each of these structures has characteristics that suggest differential approaches if the community is to influence them. The rationalistic bureaucracy requires the outer community to have linkages with expertise to insure its message has been heard. This requirement is because this type of bureaucracy has much more specialization and rules and as a consequence the community can easily make a mistake as to the correct 
entry point. In contrast, the collegial structure-because everybody tends to do the same thing and because they tend to have face-to-face meetings of the staff-is easily reached by linkages with primary group intensity and low scope. Somewhat different in this respect is the laissez-faire system. Since each staff person does his "own thing" and there is little communication between each, it is necessary to have a linkage mechanism with high scope (i.e., one that will reach most members). Furthermore, it might be necessary to vary systematically the degree of bureaucratic and primary group intensity, depending on each member's definition of his job-as being more in the direction of experts or nonexperts. Thus, some teachers in a school will be using a pupil-centered approach, others a drill, and still others may be doing nothing.

The problems of introducing change are also different in each of the organizational structures. The rationalistic organization differentiates between policy and administrative decisions. In our scheme, the first is a non-expert task, while the second is an expert's task. This situation means that insofar as the community participates within the boundaries of the bureaucracy it can use linkages that do not simultaneously require bureaucracy and primary group intensity or close contact between primary group members and experts. By contrast, in a human relations-collegialdemocratic organization, policy and administrative decisions are merged. Each expert is assumed to have internalized the policy of the organization. For the community it means that expert tasks and non-expert tasks cannot be separated and as a consequence heavy use must be made of mechanisms that permit both dimensions simultaneously, (i.e., indigenous experts; experts with similar backgrounds; local policy boards, which have veto power over hiring, firing, and training of teachers). By contrast, in laissez-faire structures there is no way to know which linkages to use, since some teachers might operate as though administrative decisions and policy decisions are separate while others operate as though they are joined.

There is yet one final consideration of organizational structure. Up to now when we spoke of changes, we assumed that the administrative structures of the organization would be the same, but some specific activities would be changed. However, if we now consider administrative changes, it is hypothesized that where one is moving from a rationalistic to a human relations structure, it becomes increasingly important to utilize community linkages that have primary group emphasis and wide scope, because central to the human relations structure is internalization of values on the part of all members of the bureaucracy. On the other hand, the move from a human relations to a rationalistic structure might emphasize more bureaucratic intensity since it no longer becomes central for the members of the bureaucracy to internalize community values. The task of policy-making is reserved for the community members. Table 4 summarizes this analysis.

We have now designated several key dimensions of the situation that, together with our theory of differential functions of primary groups and bureaucratic organizations, enables us to state more precisely which linkages can be used most effectively by the community to change bureaucratic organizations.

\section{Summary and Conclusion}

Let us briefly summarize the major points of our paper. First, we tried to make the point that the very structures of the bureaucracy and primary groups made them powerful within their respective spheres, i.e., expert tasks and non-expert tasks. Furthermore, these two types of tasks occur in most areas of life (e.g., government, health, business, military, police) and they cannot be isolated. At the same time, it was recognized that primary groups and bureaucracies have somewhat contradictory structures. From this analysis it was suggested that any time communities sought to change bureaucracies around expert tasks, they would have to have linkages that enabled them to have advocate experts. Where they sought to change bureaucracies in non-expert areas they could utilize their own primary group members. We then went on to point out that interdependence of expert and non-expert tasks varies considerably, inside as well as outside the boundaries of the bureaucracy. As a consequence it was important to evaluate linkages on the basis of their abilities to handle both primary group and technical expertise. Finally, it was pointed out that it was necessary to take into account the number of organizations or people a given mechanism could reach. With these underlying dimensions in mind, we took twelve empirical linkages and suggested how they could be rated. We then took several aspects of social situations and showed what kinds of linkages would be optimal to both.

It is clear that our analysis is far from complete, for we are in a frontier area of sociological inquiry. Prior sociologists gave little thought to theories of link- 
Table 4/Organizational Structure and Community Linkage Mechanism

\begin{tabular}{lll}
\hline Structure & Community Initiative & Organizational Change \\
\hline $\begin{array}{l}\text { 1.Rationalistic: specialization } \\
\text { rules, impersonal, separation of } \\
\text { policy and administration. }\end{array}$ & $\begin{array}{l}\text { Linkages with experts who } \\
\text { know which part of the organi- } \\
\text { zation to approach. Need to } \\
\text { have a person who is familiar } \\
\text { with the system, e.g., ex- } \\
\text { employee who now works for } \\
\text { community. }\end{array}$ & $\begin{array}{l}\text { Linkages where expert and } \\
\text { non-expert tasks are clearly } \\
\text { diffentiated, e.g., centralized } \\
\text { policy boards that are isolated } \\
\text { from the bulk of the staff. The } \\
\text { bulk of changes require tech- } \\
\text { nical expertise. }\end{array}$
\end{tabular}

2.Collegial-human relationsdemocratic: move toward generalist, internalized policies, and committee meetings rather than rules.

3.Laissez-faire: each person does his own thing. There is no central coordination.
Linkages with low scope and with primary group intensity. All people in organization do the same thing and meet with each other so community person has only to reach one to ensure message will be heard. No detailed knowledge necessary.

Linkages with high scope are necessary because the community must reach most of the members of the bureaucracy to effect a change. For some the linkage ideally contains experts, for others non-experts, since they define their jobs differently.
Linkages that permit both expert and non-expert tasks to be evaluated simultaneously since members of bureaucracy need to internalize organizational policy to carry on their jobs. Thus decentralized boards with veto power over biring and firing would be necessary.

No way to anticipate whether linkages with primary intensity or bureaucratic intensity are best since jobs are defined differently by each member of the organization. Community must be prepared to utilize several different approaches simultaneously.
Administrative Change

The move from a rationalistic to human relations structure will require linkages that combine expert and non-expert tasks, e.g., communities in local neighborhoods play a role in training teachers, hiring, and firing.

The move from a human relations to a rationalistic structure will require linkages where expert and non-expert tasks can be separated. Move from local to central boards of education.

The move from laissez-faire to rationalistic would require linkages that keep expert and non-expert tasks separate. The move from laissez-faire to human relations would require linkages that permitted both tasks to be looked at simultaneously. ages because they either assumed that bureaucratic structures and primary groups could not exist side by side in any strong form (i.e., they must be in conflict) or thought that primary group tasks could be isolated from bureaucratic ones so that the only forms of linkages one had to deal with were those that stressed isolation. It is quite clear that our formulation is far different in emphasis than either of the two prior theories. It provides a theoretical base for community participation in bureaucracies without denying that experts perform different tasks than community members. It stresses the need to develop a linkage theory between bureaucracy and community that goes beyond isolation and conflict.

There are several major gaps in our presentation. The assumption thus far is that the bureaucracy is sitting complacently by, while the primary groups seek to change it. In a prior work an attempt was made to show how bureaucracies change primary groups (Litwak \& Meyer, 1966). The joint analysis of these two conceptual schemes must be undertaken in order to increase accuracy of prediction and policy formulation. Without going into details of other paths of inquiry that must be undertaken, we hope that this paper has been sufficiently suggestive to start others making their own inquiries. 


\section{References}

Bernstein, I. Turbulent years. Boston: Houghton Mifflin, 1970.

Blau, P. Dynamics of bureaucracy. Chicago: University of Chicago Press, 1955.

Hyman, H., \& Sheatsley, P. Some reasons why information campaigns fail. Public Opinion Quarterly, 1947, 11, 412423.

Kahn, A., Grossman, L., Bandler, J., Clark, F., Galkin, F., \& Greenwalt, K. Neighborhood information center. New York: Columbia University School of Social Work, 1966. Kramer, R. M. Participation of the poor. Englewood Cliffs, N.J.: Prentice-Hall, 1969.

Litwak, E., \& Figueira, J. Technological innovation and theoretical functions of primary groups and bureaucratic structures. American Journal of Sociology, 1968, 73, 468481.

Litwak, E., \& Meyer, H. Administrative styles and community linkages of public schools: Some theoretical considerations. In A. J. Reiss, Jr. (Ed.), Schools in a changing society. New York: Free Press, 1965. Pp.53-73.

Litwak, E., \& Meyer, H. A balance theory of coordination between bureaucratic organizations and community primary groups. Administrative Science Quarterly, 1966, 11, 31-58.

Marcuse, H. One-dimensional man. Boston: Beacon Press, 1966.

Michels, $\mathbf{R}$. The conservative basis of organizations. In $\mathbf{R}$. K. Merton, et al. (Eds.), Reader in bureaucracy. Glencoe, Ill.: Free Press, 1952. Pp.143-149.

Ogburn, W. F. The changing family. In R. F. Winch \& R. McGinnis (Eds.), Selected studies in marriage and the family. New York: Holt, 1953. Pp.75-77.

Parsons, T., \& Bales, R. F. Family, socialization and interaction process. Glencoe, Ill.: Free Press, 1955. Pp.3-33.

Perrow, C. A framework for the comparative analysis of organizations. American Sociological Review, 1967, 32, 194-208.

Purcell, F. P., \& Specht, H. Selecting methods and points of intervention in dealing with social problems: The house on Sixth Street. In G. A. Brager \& F. P. Purcell (Eds.), Community action against poverty. New Haven: College \& University Press, 1967. Pp.229-242.

Redfield, R. The folk society. American Journal of Sociology, 1947, 52, 293-308.
Rogers, D. 110 Livingston Street. New York: Vintage Books, 1969.

Simmel, G. The sociology of Georg Simmel. Edited by Kurt H. Wolff. Glencoe, Ill.: Free Press, 1950. Pp.409. 427.

Theodorson, G. A. Acceptance of industrialization and its attendant consequences for the social patterns of nonwestern societies. American Sociological Review, 1953, 18, 477-484.

Tönnies, F. Fundamental concepts of sociology. New York: American Book, 1940.

Vinter, R. Analysis of treatment organizations. In E. J. Thomas (Ed.), Behavioral science for social workers. New York: Free Press, 1967. Pp.207-221.

Weber, M. The essentials of bureaucratic organization: An ideal-type construction. In R. K. Merton, et al. (Eds.), Reader in bureaucracy. Glencoe, Ill.: Free Press, 1952. Pp.18-27.

Wilensky, H. L., \& Lebeaux, C. N. Industrial society and social welfare. New York: Free Press, 1958.

Wirth, L. Urbanism as a way of life. In P. K. Hatt \& A. J. Reiss, Jr. (Eds.), Cities and society: The revised reader in urban sociology. Glencoe, Ill.: Free Press, 1957. Pp. 46-63. 